\title{
The Commercial Impacts of Reverse Logistics in E-Commerce in India
}

\author{
Jyoti, Neetu Gupta
}

\begin{abstract}
In e-commerce business, one of the important factors is effective logistics management, specifically the backend supply chain management. Logistics management involving e-commerce can also be considered as the reverse logistics that is the procedure that works as a profit center, i.e., product returns, repairs, maintenance, recycling, dismantling, etc. This research paper has studied the commercial impact of the reverse supply chain in e-commerce in India. For the unprecedented growth of e-commerce in India, some of the major factors are the emergence of retail as a dominant segment of the market, the dedication of government to 'Digital India', and an Internet user database of $\mathbf{4 0 0}$ million. Whereas, profitability is reduced to an average percentage of $8 \%$ and $15 \%$ of the total costs of logistics in the industry is represented by the average costs of reverse logistic. This research is centered upon local garments manufacturers and shoe manufacturers which provide 30-45 days of return and face complexities in reverse logistics.
\end{abstract}

Keywords: E-Commerce, India, Logistics, Supply Chain.

\section{INTRODUCTION}

Logistics plays a key role in monitoring the inflow and outflow of goods from a warehouse and their return policy also .An efficient logistics system can save millions in a business unit .According to Cambridge English dictionary, "logistics is careful planning for a complicated activity so that it happens in a successful and effective way". In supply chain management this is related to delivery of finished products from production line to the warehouse and further to the customers. According to Kayikci (2019), the way resources are shipped, stored, and obtained to the end destinations are looked after under logistics. The control, execution, and planning of the placement and movements of these services and goods regularly take place. On similar lines, reverse logistics is a term coined in 90's due to changes in environmental laws and state policies. It involves processes that involves activities that take place after the sale of products. It generally involves return of a product from customer and sending it further for refurbishment, service and recycling. E-commerce returns in the reverse logistics are a bit different from regular supply chains .In Ecommerce products are not used by customers and returns are generally received after 15 days .

Revised Manuscript Received on February 05, 2020.

* Correspondence Author

Ms. Jyoti, Department of Mathematics, J.C.BOSE University of Science \& Technology, YMCA, Faridabad, Haryana, India. Email: Jgrover1981@gmail.com;

Dr. Neetu Gupta, Department of Mathematics, J.C.BOSE University of Science \& Technology, YMCA, Faridabad, Haryana, India. Email: Neetuymca@yahoo.co.in

(c) The Authors. Published by Blue Eyes Intelligence Engineering and Sciences Publication (BEIESP). This is an open access article under the CC BY-NC-ND license (http://creativecommons.org/licenses/by-nc-nd/4.0/)
To satisfy the customers demand the companies frame policies that suit the customer, but there exists a lot more behind this process. The online shopping sites offer special advantages for products with a longer life cycle e.g. clothes and shoes. The customer is provided 30-45 days for easy return.

The key objective of this paper is to study the commercial impact of reverse supply chain in e-commerce in India.

\section{LITERATURE REVIEW}

Logistics and supply chains have always been open to introduce new technological developments, Supply chain managements has undergone a lot of changes in the past decade E-commerce has brought advanced methodologies in supply chains Kayikci(2019). Jap, S.D.(2007) earlier predicted the impact of closed loop supply chains on the buyers of products and the sellers too. Molla, A. (2007) predicted e-commerce and its benefits in developing countries. Terzi, N. (2011) studied the impact of rising ecommerce trends and gave an estimate regarding the future growth. Biswas (2018) highlighted that for the unprecedented growth of e-commerce in India, some of the major factors are the emergence of retail as a dominant segment of the market, the dedication of government to 'Digital India', and an Internet user database of 400 million. Wang et al., (2019) suggested that the revenue of the ecommerce of India is expected to increase to 120 billion USD in 2020, increasing at a yearly rate of $51 \%$. The reverse logistics involve replacements, disposal, and recycling, repairs, reselling returned products, exchanges and returns. The flow of reverse logistics also involves the complete ownership cost, energy used in the complete process, distance, percentage of cost recovery, handling cost per item, percentage of recycled material, disposition of cycle time, and amount of resold and returned products. Dutta et al (2020) tried out in developing sustainable ecommerce model for Indian markets. A multi objective optimization model is developed by them.

In the areas of reverse logistics of the supply chain, an impact by return policy decisions and pricing areas have been found in both indirect and direct channels of distribution. These impacts also involve the impact of discounting of price on inventory level and ordering decision. Moreover, an increasing amount of attention has been acquired both from the industries and from the academic world by reverse logistics (Zhang, Dong \& Sarker, 2018). There are numerous reasons for this. In 1997, $\$ 862$ billion was the total cost of logistics (Zhang, Dong \& Sarker, 2018). Besides, the wastages from the system can be minimized through effective utilization of resources and implementation of practices of reverse logistics. 
This is one of the biggest reasons why various Indian industries are not able to consider the benefits gained from practices of reverse logistics. Before the implementation of reverse logistics, it is important that the Indian industries have discussed and identified the logistic issues that can be faced in Indian conditions.

Some of the challenges faced by e-commerce retailers in India are:

On the customers part ,the reasons that initiate the process of reverse logistics is wrong size or color, returns involve no cost, ease of exchanging the item with another of same cost, ease to return unwanted gifts.

For a retailer or for the supply chain things that matter the most are framing customer friendly policies, handling the returned goods, making a detailed record of reason of return, to decide about restocking or discarding the items ,monetary loss involved .All these things make it difficult for a retailer to handle the products that come through reverse logistics. This process of returning the products in the recent years have become an essential part of the online shopping cycle .The customers want flexible return policies and suppliers are bound to provide flexible returns policies as the customer does not gets the privilege of checking the things by his own hands. The returns in the e-commerce cost three times more than the first shipping but still the companies are providing customers with easy returns policies.

The major challenges faced by Indian E-commerce retailers are:

- High volume of returned goods

- Costs involved in receiving returns

- Lack of human resources for handling returns

- Maintenance of reasons of return (data for future sales)

- Management of returns (restock or discard)

- Government policies

- $\quad$ Legal issues (for expensive items)

Some of the common challenges of reverse logistics that have been found in the environment of Indian Business are quantity of product return, kinds of products returned by customer, decision-making in operation of reverse logistics, the ratio of reverse logistics cost to cost of total logistics, the impact of return on profit, the impact of used product return on profitability of the company and liberal return policies .

\section{NEED OF THE STUDY}

After going through the literature available and the recent ecommerce policies of Indian government. We observed that the returns are most difficult to handle for the manufacturers that sell products with a longer life cycle e.g. clothes and footwear. The comfort of shopping from online stores has increased the sales and competition among the E-commerce sector. On the other hand it has also triggered huge amount of reverse logistics especially in sale period. The local garment and shoe manufacturers have to become a supplier of these E-commerce retailers and agree upon the flexible return policies. In our study, we will analyze these particular industries. The major E-commerce retailers in India are: Amazon, Myntra, Flipkart. These retailers publish the data about sales during peak festive season but there is no authentic data available about the returns received after these sales and the monetary loss during this return process.

\section{RESEARCH METHODLOGY}

To accomplish the research objective stated above, we designed a questionnaire that is designed to seek answers regarding the point of view of these suppliers and the commercial loss they have to bear. We used deductive approach and chose the method of telephonic interviews, purposive sampling method was used and snowball method was used for obtaining valid data. The total sample size reached was 300 manufacturers spread all over Indian states who are supplying goods to E-commerce retailers. All the respondents are supplying goods for more than an year and are very much aware of E-commerce policies in India. The product range of these respondents manufacture and sell garments for ladies (115), kids(52) and men(73)

The other set of respondents deals with ladies shoes(23), Men shoes(20), kids footwear(17).The respondents maintain inventory for average orders they receive in one week ,which is different for different products .In the sale period, the inventory is doubled to meet increased orders .

\section{FIGURES AND TABLES}

Analysis of responses received:

As the respondents handle different products and the percentage of returns differs for different products, the results are presented in Table I

Table I: percentage of return in general

\begin{tabular}{|l|l|}
\hline Ladies garments & 25 \\
\hline Kids clothing & 30 \\
\hline Men clothing & 10 \\
\hline Ladies shoes & 20 \\
\hline Kids shoes & 15 \\
\hline Men shoes & 12 \\
\hline
\end{tabular}

\section{Percentage of Return in general}

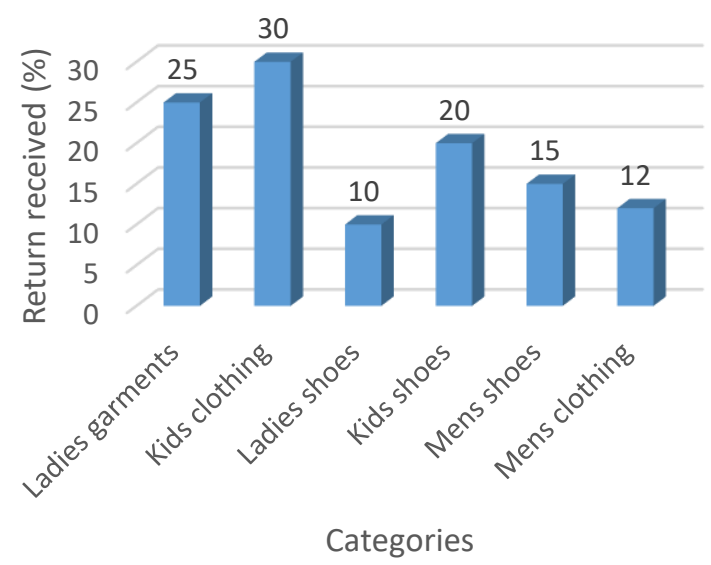

Fig. 1: Percentage of return in general

During sale periods or festive season in India, people love to buy gifts and new clothes. There is a rise in sale of almost all kind of products. 
Garments and shoes have 30-45 days return policy, therefore the returns are maximum in these categories.

Table II: percentage of return in sales period

\begin{tabular}{|l|l|}
\hline \multicolumn{1}{|c|}{ Ladies garments } & 42 \\
\hline Kids clothing & 40 \\
\hline Mens clothing & 25 \\
\hline Ladies shoes & 40 \\
\hline Kids shoes & 34 \\
\hline Mens shoes & 30 \\
\hline
\end{tabular}

\section{Percentage of Return in Sales} Period

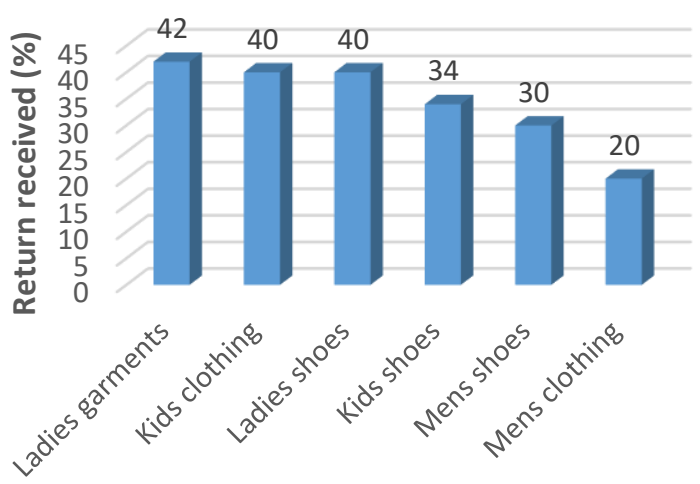

Categories

Fig. 1: percentage returns during sale periods

\section{Comparison of return rate}

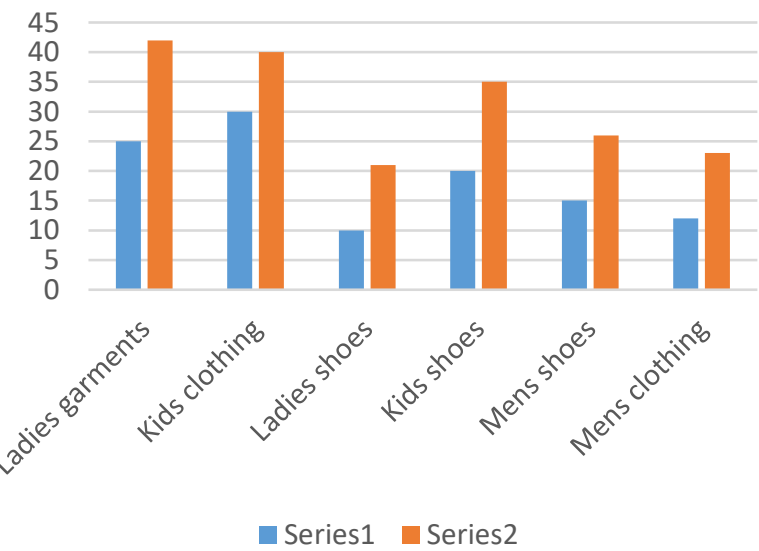

Fig. 3: comparison of return rates in general and during sales period

In general the E-commerce sites provide some options when customer wants to return a product, manufacturers also classify these returns in different groups to maintain data and for further improvement of controlled factors.

Table III: Reason of return

\begin{tabular}{|l|l|}
\hline Defect in manufacturing & 8 \\
\hline Size issues & 25 \\
\hline No reason & 5 \\
\hline Quality issues & 15 \\
\hline ordered by mistake & 3 \\
\hline
\end{tabular}

Respondents along with increase in sales also face some challenges due to very liberal return policies, the percentage is recorded in next table. The Likert scale goes from most important to least important.

Table IV: Respondents response on challenges with liberal policies

\begin{tabular}{|l|l|}
\hline Long return period & 36 \\
\hline Return fraud & 48 \\
\hline Restocking & 15 \\
\hline Replacement record & 24 \\
\hline Managing accurate record & 19 \\
\hline
\end{tabular}

\section{Challenges with liberal policies}

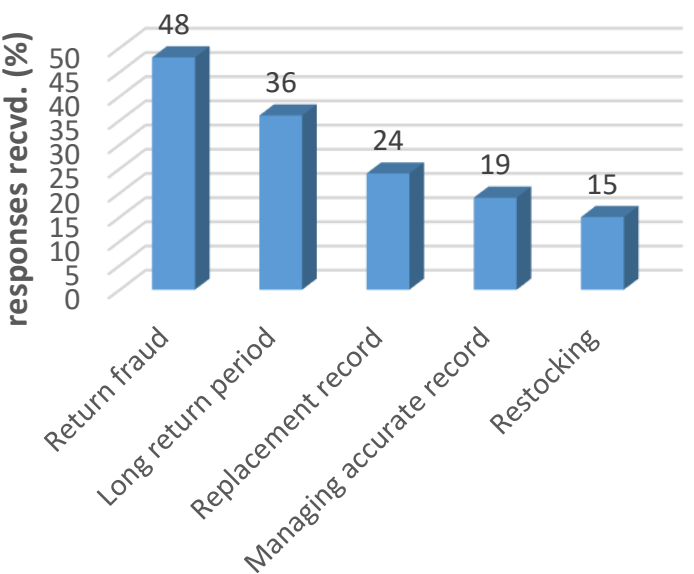

Challenges with Return

Fig. 4: Challenges with liberal policies of E-commerce

On collection of approximate data of sales from respondents, the sale value of products is compared and the percentage increase calculated. The comparison shows the increased sales due to more visibility and easy ordering of products.

Table IV: Percentage increase in sales with E-commerce

\begin{tabular}{|l|l|l|l|}
\hline Category & $\begin{array}{l}\text { Before } \\
\text { E-com } \\
\text { (in INR in } \\
\text { lakhs)) }\end{array}$ & $\begin{array}{l}\text { With E- } \\
\text { com } \\
\text { (in INR } \\
\text { in lakhs) }\end{array}$ & \% Increase \\
\hline Ladies garments & 39.5 & 53.4 & 35.18 \\
\hline Kids clothing & 22.6 & 31.2 & 38.05 \\
\hline Men clothing & 44.8 & 55.7 & 24.33 \\
\hline Ladies shoes & 16.4 & 28.1 & 71.34 \\
\hline Kids shoes & 14.5 & 19.8 & 36.55 \\
\hline Men shoes & 23.2 & 39.8 & 71.55 \\
\hline
\end{tabular}

The major drawback of E-commerce is the loss due to returns received, this was negligible before introduction of E-commerce.

Table 6: Monetary loss due to returns

\begin{tabular}{|l|l|}
\hline Category & INR(In lakhs) \\
\hline Ladies garments & 6.8 \\
$\begin{array}{l}\text { Published By: } \\
\text { Blue Eyes Intelligence Engineering } \\
\text { \& Sciences Publication }\end{array}$
\end{tabular}


The Commercial Impacts of Reverse Logistics in E-Commerce in India

\begin{tabular}{|l|l|}
\hline Kids clothing & 4.3 \\
\hline Men clothing & 4.2 \\
\hline Ladies shoes & 5.6 \\
\hline Kids shoes & 3.5 \\
\hline Men shoes & 6.4 \\
\hline
\end{tabular}

\section{Monetary loss due to returns}

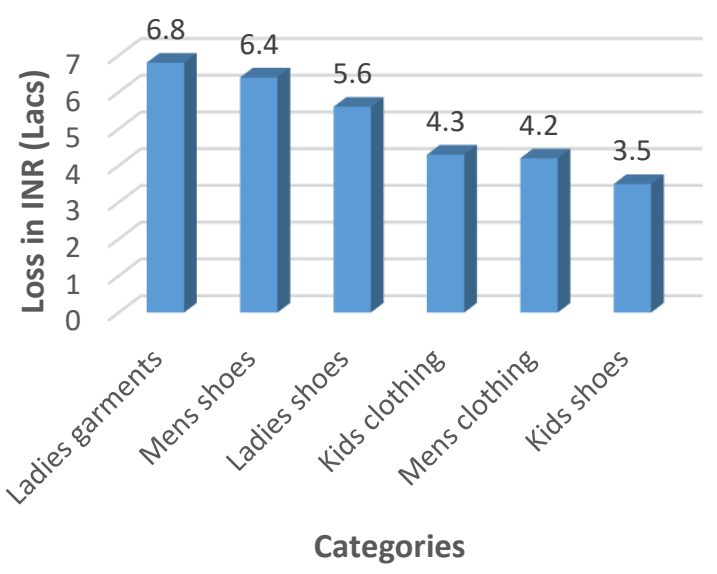

Fig. 5: Monetary loss due to returns

The final question asked was: whether you will continue with $\mathrm{E}$ commerce despite of the losses you bear in form of returns? Will you like more strict return policies? Most of them wished to continue with E-commerce as it creates large customer base for selling their products. However, they want reduced period of return and better policies to prevent huge losses due to returns in sale period. The impact of these losses encourages fake discounts on internet sites wherein the original price is inflated during sale period. To meet the competitive rates in ladies garments and kids clothing, quality standards are reduced .73\% respondents suggested that all these issues can be resolved,provided that the sales as well as the profit of these suppliers increases proportionally. E -retailers can adopt new return policies to obtain quick returns with reduced costs.

\section{RESULTS AND DISCUSSION}

From the data analyzed, it is evident that there is a sharp upsurge in returns during sale period, the maximum returns are noticed in the ladies garments and kids shoes. The key challenge that these manufacturers face is the return fraud which can be defined here as return of used items or damaging the products and claiming returns due to "no question policies", these kind of fraud returns impact the profits as most of the items are sent to outlet stores or donated. Moreover, the returns are generally received after 20 days period and garments and shoes industry is ruled by fashion trends, so they have to reduce the costs for immediate resale. Therefore, manufacturer loses a lot from the expected profits. Maintenance of replacement records e.g. size issues are a challenge. Efficient management of returns in the data base is a challenge after sale period is over. The increase in sales is lucrative for local suppliers but the costs involved with returns is also appalling sometimes and lessens profit margins between 8 to 15 percent. It has been found that the $\$ 160$ billion industry of Indian logistics is disrupted by reverse logistics or management of the process of product return. The silver lining is that, around 10

lakh jobs will be created by e-commerce in last-mile consumer delivery out of which $43 \%$ percent will be in tierIII and tier-II rural areas and cities (Dutta et al., 2020).

\section{CONCLUSION}

It can be concluded that competition, increased sales and tendency of customers to shop online is the main reason for local manufacturers to enter the e-commerce sector In the fashion driven industry of garments and shoes, it is a real challenge for local suppliers of products to meet the demands initially and suffer the losses due to returns later (figure 5).E-retailers must ensure that sale of products as well as profit of these suppliers grows proportionally. Future research can be carried out on developing reverse supply chain model to reduce losses in garment and shoes industry due to present policies. Overall profits range between 8 to 15 percent should increase to $20-25 \%$. Phenomenal growth is being experienced by the e-commerce market of India. With increasing competition, customers are acquired by providing added services and discounts by commerce giants, such as Myntra, Flipkart, and Amazon. These e-commerce giants can adopt trial and on spot return on a minimum number of items ordered in this section of garments and shoes. This will reduce the costs borne by them in receiving returns and further reduce the period of return and fraud returns significantly. The trend of using e-commerce sites will not fade away in future too. In a developing country like India it opens up many employment opportunities too. Government and e-commerce giants must develop policies and some rules regarding return of products so that, local manufacturers can flourish their business and contribute as revenues to the Indian economy.

\section{REFERENCES}

1. Biswas, C., 2018. Efficiency Improvement in Reverse Logistics and Examining the Relationships between Refund, Return Policy, Quality Policy and Pricing Strategy in E-Commerce Business.

2. Dutta, P., Mishra, A., Khandelwal, S., \& Katthawala, I. (2020). A multi objective optimization model for sustainable reverse logistics in Indian E-commerce market. Journal of Cleaner Production, 249, 119348.

3. Kayikci, Y. (2019). E-Commerce in Logistics and Supply Chain Management. In Advanced Methodologies and Technologies in Business Operations and Management (pp. 1015-1026). IGI Global

4. Wang, Y., Jia, F., Schoenherr, T., Gong, Y. and Chen, L.( 2019), Cross-border e-commerce firms as supply chain integrators: The management of three flows. Industrial Marketing Management.

5. Zhang, R., Dong, Y., \& Sarker, B. R. (2018, August). The Forming Mechanism and Actions on Returns Reverse Logistics in ECommerce Transactions in China. In 2018 2nd International Conference on Education Science and Economic Management (ICESEM 2018). Atlantis Press.

6. Jap, S. D. (2007). The impact of online reverse auction design on buyer-supplier relationships. Journal of Marketing,71(1), 146-159

7. Blasio,G.,D. (2008), "Urban-Rural Differences in Internet Usage, eCommerce, and e-

8. Banking: Evidence from Italy", Growth and Change, 39.2 , pp. 341367

9. Molla, A., and Heeks, R. (2007). "Exploring Ecommerce benefits for businesses in a developing country". The Information Society.

10. Terzi, N. (2011). The impact of e-commerce on international trade and employment. Procedia - Social and Behavioral Sciences, 24, 745-753. 


\section{AUTHORS PROFILE}

Mrs. Jyoti, has done Masters in Mathematics from Himachal Pradesh University, Shimla. She is currently pursuing her Ph.D. in Department of Mathematics, YMCA University of Engineering and Technology. She has a teaching experience of 12 years .Her main interests are Operations research and Differential Equations.

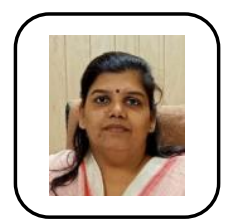

Dr. Neetu Gupta, presently leads the Department of Mathematics, YMCA University of Science and Technology. She has a teaching experience of 15 years and has contributed in many research papers, published in reputed journals. She is presently guiding Ph.D. students and has earned a good name Operations research and Numerical Analysis. 